This item was submitted to Loughborough's Research Repository by the author.

Items in Figshare are protected by copyright, with all rights reserved, unless otherwise indicated.

\title{
Democracy, capital, and the rise of the new inequality
}

PLEASE CITE THE PUBLISHED VERSION

http://dx.doi.org/10.1177/0090591717693754

\section{PUBLISHER}

(c) SAGE Publications

\section{VERSION}

AM (Accepted Manuscript)

\section{PUBLISHER STATEMENT}

This work is made available according to the conditions of the Creative Commons Attribution-NonCommercialNoDerivatives 4.0 International (CC BY-NC-ND 4.0) licence. Full details of this licence are available at: https://creativecommons.org/licenses/by-nc-nd/4.0/

\section{LICENCE}

CC BY-NC-ND 4.0

\section{REPOSITORY RECORD}

Parvin, Phil. 2019. "Democracy, Capital, and the Rise of the New Inequality". figshare. https://hdl.handle.net/2134/24813. 
Alan Thomas (2016) Republic of Equals: Predistribution and Property-Owning Democracy (Oxford University Press).

John Tomasi (2012) Free Market Fairness (Princeton University Press).

1. The Rise of the New Inequality.

Fewer people are in extreme poverty now than ever before in history. Of the $1.1 \mathrm{~b}$ people living on the Earth in 1820 over $1 \mathrm{~b}$ were in extreme poverty, cut off from a rich elite who controlled the lion's share of the world's wealth and resources (Piketty, 2013). Two hundred years of economic growth, driven in part by capitalism and free trade, has transformed the world by increasing the incomes of many of its poorest inhabitants. Poverty has fallen continuously over this time, despite a seven-fold increase in the size of the population, and is three times lower now than it was in 1970 (Bourgiugnon \& Morrisson, 2002). It has not disappeared, of course. Indeed, it exists on a massive and tragic scale. 1.3b people throughout the world still live in extreme poverty, $805 \mathrm{~m}$ do not have enough food to eat, and around 750m do not have access to clean drinking water (World Bank, 2016). These numbers belie the egregious and widespread harms suffered by vast numbers of the world's population, and also the entrenched inequalities in power and influence between rich and poor states, often reified in multi-lateral treaties and coercive trade deals, that produce them. It also suggests the need to do something to unravel the enduring patterns of global wealth which have left so many in such dire need. Nevertheless, data produced by the World Bank, which monitors global poverty across a range of indicators, strongly suggests that these patterns are being unravelled and that aggregate rates of poverty are falling year on year. 
Meanwhile, the same energies of growth, experimentation and risk that define capitalism and which have contributed to the reduction of poverty within and among states on the world stage have at the same time created vast inequalities in wealth within and among these same states. The figures are startling. $60 \%$ of Europe's wealth is owned by the top decile, and in the US the top $1 \%$ of America's income earners have more than doubled their share of the nation's income in since the mid-20 ${ }^{\text {th }}$ Century (Piketty, 2013). Furthermore, the rise in the wealth of those at the very top - the top $0.1 \%$ - has outstripped the other $0.9 \%$, increasing 7.5 times between 1973 and the present, an upward trend broken only briefly by the 2008 global financial crisis (Saez \& Zucman, 2014). The share of the household wealth held by the top $0.1 \%$ of Americans grew from $7 \%$ in 1980 to $22 \%$ in 2010. The top $0.1 \%$ in the US currently own as much wealth as the bottom $90 \%$ (Hacker \& Pierson, 2011; Runciman, 2011; Saez \& Zucman, 2014). In 2014, US bankers working on Wall Street were awarded $\$ 27.5 b$ in bonuses in addition to their regular salaries, double the combined salaries of all Americans working full-time at the federal minimum wage. And Oxfam has suggested that the 62 richest individuals in the world currently own the same amount of wealth as the poorest $50 \%$ of the Earth's population (3.6b people) (Hardon \& Ricardo, 2016).

So while global poverty has declined in recent years, global inequality has not only endured but worsened. The reasons for this are manyfold, but at heart concern the fundamental internal logics and incentives that characterise markets. Two of these in particular have driven the rise of what Alan Thomas and Thomas Piketty, among others, have called a New Inequality between and among states (Thomas, 2016).

The first is that capitalist markets entrench asymmetries in access to capital. As capital tends to grow in value faster than the overall economy, returns on capital investment have in the past century become an increasingly large percentage of individuals' overall wealth (Piketty, 2013). As a consequence, those who own property but receive a low income will, broadly speaking, accumulate 
wealth faster and in greater quantities than people who own little but receive higher incomes. Similarly, rentiers - whose income is directly tied to the value of their capital assets - see their overall wealth grow faster than those whose income is tied to growths in GDP, as do those whose wealth is composed primarily of capital investments, stocks, and shares (Hacker \& Pierson, 2011). The implications of this for egalitarian political philosophers, politicians, and activists are profound, for it suggests that the central question is not how to most effectively ensure fair inequality of income, but how to fairly distribute capital. The failure of liberal democratic states to tackle concentrations in capital ownership among their populations has resulted in larger and larger concentrations of wealth in the hands of a smaller and smaller number of high net worth propertyowners.

The second is that as the share of global wealth has become increasingly and disproportionately concentrated among an ever-diminishing number of the super-rich property-owners, so these same super-rich individuals have been able to protect their wealth in ways which are not open to the less wealthy. We can see this at both the domestic and the global levels. Domestically, the wealthy - by participating more actively and in higher numbers in democratic politics - have been able to 'shift the tax burden further down the wealth and income scale' (Thomas, 2016; p. 169). This is most obvious in the US, in which the rise of a super-rich 'civil oligarchy' has been facilitated by, and resulted from, the power of economic elites to exert political pressure on politicians - both through their greater numbers at the ballot box, and through their ability to leverage the power of lobbyists and special interest groups - not only to shift their tax burden onto the less wealthy, but also to complicate the tax code in such a way as to make its navigation dependent on expensive expert advice which is not available as easily to the less wealthy (Winters, 2011). As Thomas puts it, the 'very wealthy in American society collectively constitute an unusual powerful actor that works to roll back the state, extend the scope of market provision, lower direct and indirect taxation and transfers, and conceptualize social programs as an inefficient form of "insurance"' (Thomas, 2106, p. 
112). The overall effect of this has been to stifle initiatives capable of alleviating inequalities in wealth and income, and also to squeeze middle-income earners by making them contribute disproportionately high amounts of tax relative to wealth. In liberal states around the world, the rich have got richer, the people in the middle have got poorer, and the poor have stayed poor.

More globally, just as there has arisen in many liberal democratic states a stratum of expert legal and financial experts, as well as a network of lobby groups and non-state organisations, dedicated to helping the wealthy avoid paying tax, so there has also arisen a new a new global network of institutions, organisations, and financial arrangements which enable the wealthy to protect their fortunes from prying eyes and also from tax authorities (Thomas, 2016). That the rich are able to access a complex global web of shell corporations, international brokers, and off-shore tax havens in order to keep their wealth secret, evade tax and international sanctions, and commit fraud has been an open secret for decades, but the scale at which this is happening, and the numbers involved, have only really become clearer in the in the wake of recent media attention and leaks (Shaxston, 2011). The so-called 'Panama Papers', for example, revealed that over 140,000 of the world's wealthiest individuals, including national leaders, current and former politicians, and business people used the services of the world's largest off-shore law firm Mossack Fonseca to insulate their wealth in this way. Many other such companies exist but due to the shadowy and complex nature of this industry, working as it does at the threshold of legality across numerous political jurisdictions, the true extent of the capacity of rich individuals and corporations to avoid (or evade) paying the taxes that everyone else has to pay, and to abide by the laws that the less wealthy have to abide by, is not (and perhaps cannot be) truly known. The most recent estimate is that 1 in every 10 dollars of global financial assets are hidden in tax havens (Zucman, 2015).

Possible responses to these developments, and to the rise of the New Inequality more generally, appear on a spectrum depending on how strongly one wishes to defend markets, either as required 
by individual liberty or as a solution to poverty, and how important inequality is as compared to poverty. Indeed, there is arguably nothing in any of these facts which suggests that we should be concerned about inequality as opposed to poverty. This disagreement about the relative importance of inequality and poverty and, hence, about the desirability of markets, drives much of contemporary Anglo-American political philosophy and in particular drives recent debates between libertarians and liberal egalitarians about justice. Indeed, the lack of shared intuitions about this issue arguably accounts for the lack of progress in resolving these debates. While on one side, classical liberals and libertarians like John Tomasi have argued that justice is best served by minimal states presiding over market economies because these kinds of regimes have the best track record in ensuring the requisite economic growth to minimise poverty, liberal egalitarians like Alan Thomas have rejected markets for the deleterious effects that the inequalities they produce have had on human dignity, or the exercise of individual rights, or one's basic 'capabilities' or human 'functionings' (Nussbaum; Wolff \& de Shalit; Tomasi, 2012; Thomas, 2016). So who is right? What institutional regime does justice require? And on what grounds, if any, might egalitarians be justified in their concern to fight not only poverty but inequality?

2. Inequality, democracy, and markets.

In his 2012 book Free Market Fairness, John Tomasi writes that he 'does not view the extraction of wealth from any part of the population with the aim of lessening inequality' a requirement of justice, as he believes that our priority should not be alleviating inequality but eradicating poverty (Tomasi, 2012, p. 111). His is a sufficientarian position: he does not believe that states should engage in complex and inefficient forms of re-distribution in order to rectify inequalities created by markets, rather he believes that liberal states should allow markets to grow the wealth of all members of the political community, including the poor, in order that the worst-off might be lifted above the threshold necessary for them to become 'self-authors'. Hence, he believes, we should trust 
capitalism to do what he believes it has proven capable of doing around the world: to grow wealth in ways which increase the incomes of all people and which give individuals more control over their lives. His over-arching normative vision is of a 'market democracy': a deliberative democracy characterised by free markets, a minimal state, and a flourishing civil society. It is of a democratic society in which all individuals 'have an equal share in fundamental political power' and, in doing so, govern themselves through liberal institutions (Tomasi, 2012, p. 88). Tomasi's aim is not to replace Rawls's theory of justice with a different one, but rather to defend this theory by proposing a regime of institutions more suited to realising it than Rawls's own. Tomasi claims to find Rawls's theory of justice as fairness 'compelling' and claims also to share Rawls's claim that 'a set of political and economic institutions, in order to be fully justified, must be expected to work to the benefit of the least well-off' (Tomasi, 2012, p. 127). His claim, however, is that a market democracy-committed to protecting to individuals' economic liberty at the constitutional level - is needed to realise this goal, rather than a Rawlsian property-owning democracy which unduly restricts individuals' capacity to exercise control over their holdings and, hence, to rationally pursue a conception of the good life.

Tomasi does not discuss the rise of the New Inequality, the consequences that it has had on individuals living actually-existing states, or what its rise tells us about markets more generally. This is problematic for Tomasi in a way that it is not for many other classical liberals and libertarians because, unlike them, he believes in the importance of democracy to the protection of freedom. While Hayek and other more contemporary classical liberals have remained ambivalent in their support for democracy, and of the importance of the political liberties, Tomasi believes that the ability to exercise the basic political liberties (including the ability to participate on equal terms in the democratic process) is central to the protection of peoples' ability to be an author of their own lives (Brennan, 2011; Hayek, 1944; Tomasi, 2012). 
Tomasi thus ignores what Alan Thomas, in Republic of Equals, takes to be one of the central lessons to be learned from the rise of the New Inequality, and of economic inequality more generally: that economic inequality translates into political inequality and, hence, that inequality (not just poverty) is an impediment to realising the kind of democratic society that Tomasi believes is crucial to the realisation of justice. This is visible at the level of theory and practice, Thomas argues. Inequality, and the rise of the New Inequality in particular, has had a profound and debilitating effect on democracy in many states in that it has served to entrench political power and influence among certain individuals while ensuring the exclusion of others from the democratic system (Gilens, 2014). Liberal democratic states are increasingly dominated by socio-economic elites who in controlling the distribution of economic and social goods among citizens, and having privileged access to the formal machinery of government, are able to exercise power in ways which serve their own interests and entrench their structural dominance over time. A state which allows wealth to become concentrated in the hands of a small elite allows political power and influence to be so concentrated. And a global economy which enables economic elites to insulate their wealth from mechanisms designed to distribute it more fairly, or which enable elites to keep the extent of their wealth a secret, allows elites to insulate their power and influence from mechanisms designed to distribute political power more fairly, and hide the extent of their influence, on the world stage.

Furthermore, while the destructive effects of the New Inequality are visible at the elite level of institutions and formal decision making, they are even more obvious at the level of civil society (Parvin, 2015 \& 2016). The effects of the rise of the New Inequality on the social, political, and civic infrastructure of liberal democratic states around the world is plain to see, as is the failure of these states to manage this problem, or to ensure equal and fair access to the democratic system for all regardless of wealth, background, or personal circumstances. Political participation in liberal democratic states is substantially higher among higher socio-economic groups, and substantially lower among citizens of a lower socio-economic status (Solt, 2008; Schlozman et al, 2012). 
Furthermore, political participation is lower and less stable overall in states characterised by significant inequalities, and higher and more stable in states that do not. A range of social, economic, and political changes have conspired to cause aggregate declines in political participation and a disproportionately steep decline in participation among citizens at the bottom end of the wealth and income distribution. In contemporary liberal democratic states, the poor have not just lost their share of national and global wealth, but also the social context and the sense of social connectedness in which political participation is rendered meaningful and possible. The inequalities created by capitalist markets have wreaked havoc on the civic infrastructure of liberal democratic states, destroying traditional associational life, and eviscerating the public sphere of those forms of social connectedness and community which foster social capital and which have traditionally mobilised political activity and educated citizens about politics, in ways which have had a disproportionately negative impact on the poor. Grassroots political movements and organisations which traditionally mobilised working class citizens to political action, represented their interests in the public sphere, provided political knowledge, and helped provide a common sense of identity have in the past three decades been slowly eclipsed in number and significance at the domestic and international levels by the rise of a new stratum of elite, professional lobby organisations more suited to representing the interests of social and economic elites (Berry, 1999; Skocpol, 2003). As a result, the business of democratic politics has retreated ever further from the citizenry in general. Politics has become something conducted behind closed doors by elite state and non-state actors, rather than by elected representatives who work in consultation with their constituents.

The death of traditional civil society caused by capitalism, inequality, and the rise of elite governance resulted in a participatory and epistemic vacuum which has been filled by the activities and perspectives of the most advantaged. The decline of traditional opportunities for face-to-face citizen engagement, coupled with infrastructural deprivation and a lack of investment in communal and civic life by liberal democratic states presiding over market economies has excluded entire 
demographic groups - and entire geographical areas - from the political process and has led to entrenched inequalities which endure across generations (Putnam, 2015). In the USA, residents of the most impoverished areas of Detroit, the slums of El Paso, or the Castlemont district of Oakland, for example, face a daily struggle to eat healthily, to pay their rent, to educate their children and keep them safe, to breathe non-polluted air, or to afford healthcare for themselves or their families. In these places and others like them, where the local industries have shut down and the businesses have moved out; where the grocery stores have been replaced with fast food restaurants; where the schools are unsafe, underfunded, and lacking in resources; where drugs are openly sold on street corners and crime and murder rates are high and growing; and where the basic structure of community life has fragmented in the wake of social forces beyond the residents' control, community leadership has disappeared, and life has become a daily grind characterised by intergenerational deprivation, fear, and uncertainty. It would be astounding if rates of political participation in these and the many communities like them across the US - in which activities like following political campaigns or attending town hall meetings (if you could find one) are squeezed out by more immediate and pressing concerns - were not incredibly and disproportionately low. And similarly, in Britain, in cities like Oldham and Walsall and Middlesborough, declines in local industry, changing patterns of wealth and social capital, and a lack of public investment in communities has resulted in increasing numbers of citizens finding themselves poor, isolated from one another, and isolated from a democratic system that does not speak their language, does not connect with their lived experience, conducts its business at a distance from their lives, and cannot grasp or resolve the problems they face. As the economic fortunes of the poor have stagnated, as the relative fortunes of middle-income earners have been squeezed, and as an increasing share of the wealth has accumulated in the hands of those at the very top, so liberal states have become increasingly characterised by a wealthy political class, who dominate public institutions and participate in a range of formal and informal political activities, and an apolitical class who tend to be poorer, and whose 
presence and influence is marginalised in political institutions and the wider democratic system (Parvin, 2011).

In ignoring all this, and in not sufficiently appreciating the lived experience of inequality on peoples' lives and on their ability to exercise their basic political liberties, Tomasi misses an important weakness in his theory: that the political equality he argues is central to his vision of a market democracy, and the civil society that makes this vision feasible, is incompatible with the form and extent of the economic inequalities created by markets. Moreover, Tomasi misses one of the central reasons why we should care about inequality and not just poverty: it is not merely poverty which thwarts individuals in their exercise of the political liberties, but inequality. People at the lower end of the wealth and income distribution in rich states tend to participate less frequently and in lower numbers than people at the lower end of the distribution in poorer states, even though their overall bundle of wealth and resources tends to be higher. Consequently, in order for the state to ensure that all citizens 'have an equal share in fundamental political power', as Tomasi believes they should, the liberal state would need to intervene in market transactions, and constrain economic liberty, to a much higher degree than he believes it should, in the in the interests of reducing the gap between the rich and the poor.

3. Welfare states, market democracies, or property-owning democracies?

Assuming that Thomas and Tomasi are both correct in their claim that democratic self-government is a crucial aspect of individual liberty, what should be done to tackle the economic inequalities which undermine democracy around the world, and what accounts for the failure of previous attempts by many actually-existing states to tackle them? Thomas argues that the problem lies in the lack of attention paid by many egalitarians and also politicians around the world to the centrality of property-ownership in producing unfair inequalities in wealth and power. The problem with markets 
for many egalitarians is that they do not take seriously the devastating consequences of inequality on peoples' lives, or the connection between economic inequalities and other kinds of inequality. However, the problem with egalitarians for Thomas is that they too often make the same mistake. While liberal egalitarian political philosophers have in the past pointed out that social and economic inequality tends to translate into political inequality, few have provided a normatively persuasive solution capable of addressing the deep structural inequities which cause this problem. Thomas suggests that this is because they have (a) ignored insights provided by civic-republican theory about the importance of 'domination' in public life, and (b) focused too heavily on the ability of ex-post redistribution as a means of alleviating inequality. Even Rawls, who defended quite radical measures designed to minimise the impact of social and economic inequalities on the exercise of the political liberties, failed to adequately tackle the problem because, Thomas argues, the economic inequalities permitted by the difference principle were incapable of securing the 'fair value' of the political liberties. In reality, and in Rawls's theory, wealthy elites are able to leverage their assets in ways which allow them to exert sometimes benign, but also malignant, control over the political agenda and the course of decision making, and they are enabled in doing so by virtue of the wealth they have accumulated through their ownership of property. They are able to dominate the political process (in a civic-republican sense) by using their undue influence to control the 'effectiveness of the basic liberties possessed by the worst-off' and selectively 'reduce the effectiveness of the basic liberties more generally' (Thomas, 2016, p. 106). In market capitalist societies civil oligarchs have proven themselves able not only to take control of government, but also to roll back its scope, to seek the reduction of the size of the state, 'so that they can exercise their dominant economic position in the form of private governance unhindered by state regulation' (Thomas, 2016, p. 107). Consequently, Thomas argues, any egalitarian system which does not seek to reduce the 'domination' of the poor by the wealthy at the same time as reducing inequalities in access to property simply leaves intact the structural asymmetries which give rise to, and drive, the creation of political inequalities in the first place. 
Thomas therefore supports Rawls's critique of free markets and also welfare state capitalism and argues for the need to establish an egalitarian property-owning democracy in their place which draws on, and extends, Rawls's own vision of such a regime. Welfare state capitalism or free market capitalism of the kind defended by Tomasi do nothing to dismantle the over-arching patterns of unequal wealth and capital ownership which are created by capitalist markets and permitted by political institutions charged with their protection and maintenance, he argues. Welfare states and initiatives like a Universal Basic Income blunt the effects of capitalist markets on the least advantaged by providing them with a safety net but they do not sufficiently address the background incentives and mechanisms which create and entrench the creation of these inequalities at root and which make the ongoing intervention in markets necessary. A just society - for Rawls, and for Thomas - is a well-ordered society in which citizens are motivated by a sense of justice and norms of reciprocity which are absent in welfare-state capitalist regimes, and in which individuals not only formally possess equal political liberties but also enjoy the ability to exercise these rights meaningfully on an equal basis.

Justice, for Thomas, therefore requires two things. Firstly, it requires the rejection of initiatives like redistributive progressive taxation and a Universal Basic Income which leave intact market incentives which produce inequalities in favour of a much more radical egalitarian recalibration of property-ownership in liberal states, and in particular the unravelling of entrenched and hereditary patterns of property-ownership, which give rise to unequal concentrations of wealth that can be observed in states throughout the world. Components of such a radical re-ordering of the macroeconomic background of society go beyond conventional egalitarian commitments to free healthcare, education, and other social goods and include in addition such measures as more substantial taxes on inherited wealth and property, stronger workers' rights, workplace democracy, and a more equitable distribution of ownership of the means of production among citizens in order 
to ensure that society 'is not so divided that one small sector controls the preponderance of productive forces.' (Rawls, 1971; p. 280). Secondly, it requires a regime of checks and balances which ensure that economic elites cannot exert disproportionate influence in the democratic system. In arguing as much, Thomas reconstructs Rawls's theory of justice as drawing not only on both the civic-republican tradition of philosophers like Pettit but also the predistributive tradition of thinkers like Meade and - arguably - Piketty who have argued that instead of constantly seeking to rectify the unjust inequalities created by markets through intervention, a liberal state should preconfigure the institutions of a liberal society in such a way as to ensure that the distributive patterns that they create are just (Meade, 1993; Pettit, 1997; Piketty, 2013; Rawls, 2001). A just society is one in which capital is fairly dispersed among citizens rather than concentrated in the hands of the few such that the uncoerced transactions of citizens result in patterns of distribution which are fair. The hope, shared by Rawls, Thomas, and other members of the predistributive tradition is that the preconfiguration of the institutions of the basic structure of society along egalitarian lines, and the widespread dispersal of property among citizens in line with the wider commitment to fair equality of opportunity, will lessen the need for ex-post state intervention in market outcomes by ensuring that these transactions are made against a background of fair inequality in access to those resources necessary for the free exercise of the basic liberties.

4. Democracy, Equality, and the Importance of Normative Theory

Thomas's vision of an egalitarian property-owning democracy is a powerful and compelling one. In drawing on civic-republicanism to highlight both the deficiencies of Rawls's political liberalism and also the specific challenge to democracy and freedom posed by the rise of the New Inequality, Thomas arguably provides the best hope that liberal democratic states have for ensuring greater justice and also repairing what has broken in our current democratic theory and practice. 
Neither Tomasi nor Thomas offer visions that will prove popular with the governments or the vast majority of citizens of liberal democratic states around the world, however. For the events of 2016 have revealed all too starkly the disconnect between the appeal of democracy among many political philosophers and the operation of democratic politics on the ground, and also the fragility of the basic normative and methodological assumptions which unite these works: that democratic ideals are important and should be defended and that political truth is revealed through abstract rational reflection on facts about the world. They have also arguably revealed the antipathy that many citizens have for the concerns that drive many egalitarian and also libertarian political philosophers and the methods they propose to consider and resolve them. The rise of populism in the UK, the USA, and much of Europe, and the fact that increasing numbers of citizens of states throughout the world have embraced inegalitarianism, pose a bleak challenge to political philosophers like Thomas and also Tomasi who, despite his normative differences with Thomas, is nevertheless also committed to employing the tools of analytic philosophy to create 'realistic utopias' which may in turn guide our wider deliberations about justice and the purposes of liberal democratic institutions. Such a belief in the power and importance of abstract normative theorising about politics has arguably never been more out of kilter with the background tenor of political debate in states like post-Brexit Britain and post-Trump America, in which expertise and abstract political theorising have been widely rejected in favour of a more visceral pragmatism or a politics of 'common sense'. In this regard, both books - but Thomas's in particular - arguably reveal both the crucial value and also the redundancy of grand normative theorising in the Anglo-American analytic tradition. For while Thomas convincingly traces the ruinous effects of social and economic inequality on citizens and on democracy itself, and persuasively outlines the need to dismantle the economic and political elitism that has come to characterise the contemporary Anglo-American political space, President-elect Trump is - at time of writing - busy appointing some of the wealthiest people in the US to the most powerful political positions in the world, and preparing to cut corporate taxes and regulations. And while Thomas argues for extensive tax increases on wealth, stronger workers' rights, and greater 
workplace democracy, the governments of the USA, the UK, and numerous other states have called for tax cuts and less workplace democracy. Both Thomas and Tomasi would be critical of what passes for Trump's vision of a greater America: Trump's policy programme is incompatible with either conception of justice presented in these two works, as is their justification. Trump's vision is not rationally justifiable in the way that Tomasi, Thomas, and the vast majority of political philosophers assume that it should be. Indeed, the rational justifiability of his vision is not even considered necessary by most of his supporters. The fact that the rise of Trump and populism around the world, and the ushering in of a new era of post-truth politics on the world stage, can effectively marginalise not just Thomas's liberal egalitarianism but also Tomasi's defence of free markets, serves to confirm both the redundancy of normative political philosophy and also that rigorous theorising into the nature, scope, and content of justice of the kind practised by both Tomasi and Thomas, is more crucial, and more necessary, now than ever.

More substantibely, the events of 2016 thus pose a stark challenge to both Tomasi and Thomas who argue not only that truth about politics emerges from rigorous theorising on first principles, but also for the importance of democracy, and of deliberative democracy in particular, as a normative ideal. Recent events such as the result and conduct of the 2016 US Presidential election, and of the EU referendum in the UK, have destroyed many of the assumptions that many within and outside of the academy have long held about the progressive and redemptive nature of democratic politics, and not unreasonably. But, more specifically, they have highlighted a wider, deeper problem with democracy in the $21^{\text {st }}$ century: that while political power might in a democracy formally be shared equally, the capacity to gain political knowledge, to understand oneself as a citizen joined with others in a common political endeavour, is not. As traditional civil society, and traditional movements and associations, have declined, and as social and economic resources have become increasingly concentrated in the hands of a smaller and smaller number of high net-worth individuals capable of leveraging their substantial economic resources in ways which entrench their 
political dominance, so vast numbers of citizens have lost not only their voice in the political system, but also the sources of their political knowledge and their political identity. And as democratic politics has retreated to the elite level, these same citizens have become disenfranchised and disconnected from the very system which was, originally, designed to represent all citizens' interests equally. Thomas takes this seriously, and while his argument is utopian, he nevertheless provides an argument which seeks to replace what has been lost, to rebuild civil society, and to tackle the inequalities which have cast adrift so many poorer citizens from the democratic system. Tomasi, on the other hand, argues for the importance and centrality of political equality only to offer a vision of a society ill-equipped to secure it.

References

Berry, J. M. (1999) The New Liberalism: The Rising Power of Citizen Groups (Washington D.C.: The Brookings Institution)

Bourgiugnon, F. \& C. Morrisson (2002) 'Inequality Among World Citizens: 1820 -1992', American Economics Review 100, pp. 5-34.

Brennan, J. (2011) 'Political Liberty: Who Needs It?', Social Philosophy and Policy 29/1, pp. 1-27.

Gilens, M. (2014) Affluence and Influence: Economic Inequality and Political Power in America (Princeton, NJ: Princeton University Press)

Hacker, J. \& P. Pierson (2011) Winner Take All Politics: How Washington Made the Rich Richer and Turned Their Back on the Middle Class (New York: Simon \& Schuster). 
Hardoon, D.F.N. \& S. A. Ricardo (2016) An Economy for the 1\%: How Privilege and Power in the Economy Drive Extreme Inequality and How This Can Be Stopped (London: Oxfam).

Nussbaum, M. (2011) Creating Capabilities (Cambridge, MA: Harvard University Press).

Parvin (2016) 'Silencing the Critics: Lobbyists, Charities and the Government's Quiet War on Dissent,' Renewal, 24/3, pp. 62-95.

(2015) 'Is Deliberative Democracy Feasible? Political Disengagement and Trust in Liberal Democratic States,' The Monist 98/4, pp. 407-423.

(2011) 'Localism and the Left: The Need for Strong Central Government,', Renewal $19 / 2$.

Putnam, R. D. (2015) Our Kids (New York: Simon \& Schuster).

Rawls (1971) A Theory of Justice (Cambridge, MA: Harvard University Press) (2001) Justice as Fairness: A Restatement (Cambridge, MA: Harvard university Press)

Runciman, D. (2011) 'Didn't they notice?', London Review of Books 33/8, pp. 20-23.

Saez, E \& G. Zucman (2014) 'Wealth Inequality in the United States Since 1913" Evidence from Capitalized Tax Data' Working Paper 20625. Available:

http://gabriel-zucman.eu/files/SaezZucman2014.pdf. Accessed: 7th December, 2016. 
Schlozman, K. L et al (2012) The Unheavenly Chorus: Unequal Political Voice and the Broken Promise of American Democracy (Princeton, NJ: Princeton University Press).

Shaxson, N. (2011) Treasure Islands: Tax Havens and the Men Who Stole the World (London: Bodley Head).

Skocpol, T. (2003) Diminished Democracy: From Membership to Management in American Civic Life (Norman, OK: University of Oklahoma Press) (2004), 'Voice and Equality: The Transformation of American Civic Democracy', Perspectives on Politics 2/4 (2004), pp. 3-20

Solt, F. (2008) 'Economic Inequality and Democratic Political Engagement', American Journal of Political Science 52/1, pp. $48-60$.

Thomas, A. (2016) Republic of Equals (Oxford: Oxford University Press).

Tomasi, J. (2012) Free Market Fairness (Princeton: Princeton University Press).

Winters, J. A. (2011) Oligarchy (Cambridge: Cambridge University Press).

Wolff, J. \& A. De-Shalit (2007) Disadvantage (Oxford: Oxford Universitty Press).

Zucman, G. (2015) The Hidden Wealth of Nations (Chicago: Chicago University Press). 
